\title{
From Lagging Behind to Losing Ground: Cambodian and Laotian Household Economy and Large-Scale Land Acquisitions
}

\author{
Christophe Gironde and Gilda Senties Portilla
}

\begin{abstract}
Large-scale land deals in the agriculture and forestry sectors have significantly affected livelihoods in South-East Asia. This chapter analyses the implementation of land deals for rubber plantations since the mid-20oos and their consequences for rural livelihoods in north-eastern Cambodia and southern Laos. The analysis provides empirical material on how these deals were facilitated by previous policies and how they were implemented on the ground. It further highlights different levels of dispossession in in a series of villages studied and examines the uneven transformations in people's livelihoods. The conclusions complement scholarly assessments of land deals' immediate impact with a medium-term analysis of the consequent transformation of livelihoods. The chapter indicates that land acquisitions and related crop booms have set in motion dynamic, market-based developments including changes in social attitudes and lifestyles. Yet, the majority of the population has been caught in an insecure environment, where it is vulnerable to the opportunistic behaviours of more powerful actors. Family farming-based livelihoods are no longer 'lagging behind', as they were once considered; they are now losing ground, as opportunities to diversify their means of subsistence remain inadequate. Finally, the chapter provides policy-relevant recommendations on how to alleviate some of the worst short-term consequences for the local rural populations.
\end{abstract}

\section{Introduction}

Cambodia and Laos have both placed export-oriented, cash crop agriculture at the core of their development strategies. To do so, the two countries have leased vast areas of land to foreign and domestic companies in order that they invest in large-scale agricultural production. Addressing cases of rubber investment in Ratanakiri province in north-eastern Cambodia and Champasak

(C) Graduate Institute of International and Development Studies, 2016 | DOI 10.1163/9789004304758_008 This is an open access chapter distributed under the terms of the Creative Commons Attribution- 
province in southern Laos, this chapter analyses the implementation of these land deals and their medium-term consequences for rural livelihoods.

The chapter contributes to bridging the existing gaps in the 'land grab' literature by addressing three main scholarly challenges. The first challenge is to complement standard assessments of immediate impact—mostly measured in terms of land loss - with a medium-term analysis ${ }^{1}$ including how households respond to new constraints and opportunities, and to what extent they have, or have not, managed to adapt their productive activities to create sustainable livelihoods. The second challenge is to go beyond the winners-losers picture (Borras Jr. and Franco, 2012), which opposes outside investors and local communities, by analysing the outcomes of the social differentiation induced by large-scale land acquisitions. The third is to include various types of investors and land deals of all sizes (Edelman et al., 2013) in order to highlight to what extent different types of rubber sector land acquisitions have different consequences.

This chapter has three sections. The first presents the debate on the region's agricultural model for export-oriented cash crops and provides the analytical framework and methodology. The second section is dedicated to case studies, describing and analysing local contexts, the process of land acquisitions, and changes in livelihoods over a period of $5^{-7}$ years. In the third section we synthesise and discuss our case studies. In the conclusion we reflect on the current stage of agrarian transition in the spaces studied and draw some policy recommendations based on people's own reflections on their realities.

Research Background and Methodology

Our research relates to the debate on whether the outcomes of agrarian transitions are 'disruptive' or 'more developmentally positive' (Rigg et al., 2012, 1469-70). We discuss to what extent local livelihoods are 'disrupted' (Cotula, 2013) by large-scale land acquisitions and what new opportunities or alternative economic occupations are available in relation to such acquisitions. We also address the issue of the social differentiation that occurs in relation to the dynamics of land acquisitions and the changing farming system. More specifically, the chapter contributes to the discussion on the capacity of smallholders to engage with crop booms (Hall, 2011), in a context in which their land tenure

1 By 'medium-term', we refer to the period of 5 to 7 years that followed the acceleration of large-scale land acquisitions for rubber plantation, which occurred in 2006-08. 
and access to resources are increasingly being challenged by radical changes in property regimes and actors (Peluso and Lund, 2011; Bakker et al., 2010; Guérin et al., 2003). Our analysis is particularly inspired by the attention drawn to 'new actors' by Peluso and Lund $(2011,668)$, and the call from Tania Li (2011) for more attention to be paid to labour regimes, as non-farm job creation and access to salaried work are of increasing importance in agrarian transitions (Rigg, 2006).

Numerous South-East Asian experiences show that smallholders can grow rubber successfully (Delarue, 2011; Sikor, 2012; Sturgeon, 2012). In line with a broad consensus that public support to farmers is crucial to the diffusion of technology, the key lesson from those experiences is that farmers have been successful when they have benefited from secure land tenure (Sikor, 2012) and that their performance depends greatly on the support they receive, or do not receive, from the state (Gouyon, 1995; Fox and Castella, 2013). Another important factor in farmers' performance is the learning process, as illustrated by the cases of farmers in northern Thailand, who could learn tapping in plantations in the south before developing their own farms, and of northern Laotian farmers who benefited from 'sharecropping arrangements with relatives' from China who 'extended their rubber holdings across the border' (Sturgeon, 2012).

For Cambodia, it is argued that rubber is more profitable than other trees, such as acacias, eucalyptus, cashew nut or oil palm (Hansen and Top, 2006). The study by Fox et al. (2009) similarly shows that rubber is the best alternative to current natural forest uses and argues that it provides a 'better economic position' to local populations. And rubber is deemed attractive 'due to its fewer (agricultural) inputs, long economic life and high market demand' (CDRI, 2009, 13). Other studies draw attention to the fact that rubber plantations 'require huge investment in both financial and technical resources' (Yem et al., 2011), and that small producers might not be paid adequately for their rubber because of the commercialisation system (Gironde and Fortunel, 2014). Predictions made over the last decade are not optimistic about the sustainability of local populations' livelihoods, particularly when considering the rate of forest loss (Fox et al., 2008), the unavoidable abandonment of traditional farming practices (Ruohomäki, 2004), and 'neo-patrimonialism' practices and abusive power relations (Un and So, 2011; Ironside, 2009). As most populations are left out of complex registries of land-use rights (Simbolon, 2002; Luco, 2008) the risk of marginalisation and forced displacement is deemed high, in particular for ethnic minorities (Bourdier, 2009).

For northern Laos, economic gains for smallholders have been observed under certain market conditions and incentives from contract farming and governmental policies (Manivong and Cramb, 2008). However, studies have found that these investments are often accompanied by unfair and uncertain 
terms for farmers (Diana, 2008; Gerbert, 2010; Lin, 2010) and by losses in terms of food security due to soil degradation and deforestation (Luangmany and Kaneko, 2013). In southern Laos, where contract farming is unusual for rubber, ${ }^{2}$ farmers' land has been enclosed in rubber estates that are managed by public/ private (mainly foreign) companies (Schönweger et al., 2012). Engagement with rubber is limited to a few local elites who have the necessary capital and know-how. A growing body of literature has mostly documented the negative outcomes - for local communities and the environment - induced by these deals (Barney, 2007; Baird, 2011; Kenney-Lazar, 2012; McAllister, 2012). Farmers at large, however, are not necessarily averse to certain changes brought about by the rubber boom, but are limited in terms of their capital, secure land rights, and access to markets. They often become easy prey to 'price dictation, oligopsony and unscrupulous practices' (Fullbrook, 2011, 15), a risk that is more pronounced for ethnic minorities.

The case studies in this chapter are based on the authors' personal field research carried out in villages of Ratanakiri (Cambodia) and Champasak (Laos) provinces, respectively. Data were mostly collected through semistructured interviews with households, local authorities, and company representatives. Villages were selected based on the presence of large-scale rubber land concessions for at least five years, accessibility during rainy and dry seasons, and different processes of land acquisitions reported by district authorities. Fieldwork in Cambodia was spread over four 10-day missions in 2012-13, covering three villages: Pra Lai and Trang in Loum Choar Commune (O'Yadav district) and Malik in Malik Commune (Andounge Maes district). Data collection in Cambodia included a questionnaire-based survey of 240 householdsthat is to say, 24 per cent of the population of the villages. In Laos, fieldwork took four months spread across 2012 to 2014 in four villages: Thongpao, Huaytong, and Lak Sip Kao in Bachiang district, and Lak Sao Paet in Paksong district. Interviews in Laos were complemented with participant observation ${ }^{3}$ and focus group discussions with the elderly and the youth of the village.

Due to the sensitivity of the topic, interviewees remain anonymous and comments made by public officials are not openly credited to any particular

2 The government in Champasak has recently unveiled a 'land as equity' model, including rubber, in which farmers will allegedly receive more benefits as they will hold shares in the concession contracts and retain land ownership rights if a venture fails (Vientiane Times Reporters, 2015).

3 This included household activities, such as farming chores in the dry and rainy seasons, cooking and meal times, collection of non-timber forest products (NTFPs), fishing, and village festivals or social gatherings. Situations, symbols, or objects indicative of the transformation of livelihoods were also observed, such as cash-related actual work and consumer goods. 
individual. Direct quotes of respondents are not literal citations, but are translations of the original statements made in Khmer, Lao, or in the local indigenous language.

A further note on terminology is pertinent. While the term land acquisitions' is used to refer to any type of land deal regardless of origin and type of investment, (economic) 'land concessions' specifically refers to state grants of land, in either concession or lease form, to foreign and national investors in areas that are categorised as pertaining to the state (Schönweger et al., 2012).

3.1.1 Local Context and Background

In the area studied, local livelihoods - until the mid-199os - were based on customary land tenure consisting of oral recognition of farming use-rights (Springer, 2013). Families had to inform or ask the village chief or more simply agree with neighbours on the demarcation of plots to be farmed. Testimonies gathered from people native to Loum Choar and Malik, indicating that access to land was not an issue because there was plenty of land, corroborate those gathered by Fox and Vogler (2009, 316), who report on a neighbouring commune (15 km away) in which each person had access to approximately 11 hectares (ha) in the late 1980 s. Social differentiation was low with respect to farming land and access to forest areas, which provided the core of necessary resources. All families had equal access to land and equal use rights as well as access to forest resources. Families could be distinguished by their possession of cattle and buffaloes and prestigious handicraft goods (White, 1996). Food cropsmostly rice and vegetables - were dominant in a rotational cropping system including 10-15 years fallow after $2-3$ years use of the same plot. Rain-fed crops were, if necessary, completed by paddy rice in lowlands. Fruit trees, husbandry, fishing, hunting, and the collection of non-timber forest products (NTFPS) in the areas surrounding the villages completed resources from cultivation. Nonfarming activities were minimal. Cash crops, mostly soya and cashew nut, were progressively developed during the 1990 .

Prior to the mid-20oos land rush, local livelihoods were impacted by public policies implemented in the 199os. Once the state of warfare and instability ended, the government developed its administrative capacity in remote and border areas such as Ratanakiri. New villages were established closer to roads, public services, and communal administrations. Displaced inhabitants were assigned areas of land to which neither the traditional inheritance system nor communal management provided them with legitimate access and use-rights. 
At the same time, the 'Khmerisation' policy, which aimed to settle people of ethnic Khmer origin in ethnic minority areas, brought newcomers to these remote territories. Pioneer in-migrants would later open the door to their relatives and networks, which led in turn to additional cohorts of newcomers acquiring land during the 1990s, in some cases to the point where indigenous populations decided to move away from in-migrant clusters (Tang, 2014, 30-31).

Rubber plantation in Cambodia was revived from the mid-199os on, when former state plantations were privatised (Fortunel, 2014). Then, powerful members of the state apparatus and 'entrepreneurial groups sympathetic to the Cambodian People's Party' (Hugues, 2003) acquired large tracts of land, mostly for logging. In the early 200os, a series of government initiatives and development projects-model farms, planting schemes, training courses, etc. - were set up to promote rubber. Until that time, populations had preferred to invest in cashew nut; rubber being not well known and seedlings difficult to find. However, the conditions necessary for a rapid spread of rubber plantation were met. The rubber boom started with the sharp increase in rubber prices in 2005, triggering an unprecedented change in land cover and land use (Fox et al., 2008) driven by Khmer entrepreneurs (accounting for up to several hundreds ha holdings), medium-rank officials and their relatives (up to a few dozens of ha), and in-migrants (a few ha). In parallel, the first economic land concession (ELC) contracts were signed; their numbers increased from 2009 onwards. In 2012, there were 16 ELCs for a total of approximately 114,000 ha for the entire province.

\subsubsection{Land Acquisitions}

In Pra Lai, Trang, and Malik, rubber expansion started about eight to ten years ago. This is corroborated by the dominance of rubber plantations that are not yet productive, large areas of cleared land not yet planted, and the influx of in-migrants who nowadays represent 31.5 per cent (one family in three) of the total population of the two Communes in which these villages lie.

In Pra Lai village, two main investments affect the population's access to land: a 5,000 ha ELC to a Khmer-Vietnamese joint-venture named Chea Chenrith (contract signed in 2002; revised in 2012) and a Khmer company named Mekong Express, which bought 480 ha of land between 2007 and $2010 .{ }^{4}$ The closest point of the Chea Chenrith joint-venture land's perimeter is located approximately four kilometres from the village; no demarcation marks - fences, pillars, or marked trees - could be seen. The land encompasses an area that has not yet been prepared for rubber trees, and Pra Lai

4 The 480 ha now the property of Mekong Express are spread across the two villages of Pra Lai and Trang; it is not possible to quantify how much land is on each village's territory. 
inhabitants have, so far, continued farming in this area. Surprisingly, we even found rubber trees planted by villagers on land that, they say, is part of Chea Chenrith's territory. These trees-two dozen ha-belong to five well-off families, including the chief of the village and his close relatives. The rest of the Pra Lai villagers have also continued to cultivate annual crops on this unused portion of the ELC landholding. In 2012, villagers applied for the measurement of the land plots they farmed, in accordance with Prime Minister Directive 01 (Do1) (issued in May 2012), which stipulated that citizens could claim back the land plots that had been granted as part of ELCs and that they cultivated at the time when the ELC was set up. During August 2012, government officials measured a total of 173 ha of land plots; fallow land plots were not measured and are considered as being the property of the company. In Pra Lai, 72 families (56 per cent) reported that their land was measured and received land titles that, so far, guarantee that they can 'keep' these plots. The situation is significantly different with Mekong Express, which in one to two years prepared the land and planted rubber trees. No attempt by villagers to continue farming on the Mekong Express landholding was reported. Apart from the rapid plantation of rubber trees, villagers explained this situation by stating that this acquisition cannot be contested since part of the land was sold by villagers themselves, and another part was sold by representatives of the communal authorities. Villagers also reported being afraid of contesting the acquisition as the land's owner is Khmer. Furthermore, Do1 applies only to ELC-companies, not to ordinary private ones such as Mekong Express.

The situation differs in Trang where the population was impacted by Mekong Express and Khmer in-migrants. The purchases there by Mekong Express took place in two phases: in 2007-08, the company bought its first land plots directly from villagers; in a second phase, the company dealt with the local authorities and bought communal land. At the same time, the village experienced many acquisitions by Khmer in-migrants, who settled first along the main road, in Oun village, where they opened shops, restaurants, etc. They then progressively bought land plots further from the road, in Trang. The villagers explained that between 2007 and 2009, they had sold part of their fallow plots assuming that there was enough land left to be cleared for the next rotation; they simply could not have known that—at that moment—large tracts of land were in the process of being sold to Mekong Express. As a result, since 2010, Trang families have been left with stripes or dots of land between the landholdings of the migrants and the hundreds of hectares now the property of Mekong Express. The process has not stopped: about a third of Trang families (31 per cent) report that they have sold land since 2010 and 40 per cent of Trang families report having less land than in 2010. 
The third village, Malik, is surrounded by two Vietnamese ELCs-Heng Brother and Chieng Ly Investment-since they were granted, respectively, 2,361 ha in 2009 and 5,080 ha in 2011. In addition, numerous Khmers have acquired land plots on the outskirts of the village. The ELCs deprived Malik villagers not only of land they could farm but also of fishing and hunting in an area that, they explain, was particularly rich for such activities. Monetary compensation for cultivated plots-USD 150-200 per ha, based on the cost of labour for clearing - were derisory when compared to the income that could be made from certain crops on those plots. But the most important distinctive feature in Malik village is the population's response. First, Malik villagers opposed Heng Brother when the company started to expand beyond its granted area. The opposition benefited from the support of local organisations, which helped to forward villagers' formal claims to provincial government representatives. Although it is not possible in the field to measure the area that may have been saved, the Malik population certainly stopped the further expansion of the company. In parallel, those Malik villagers who had the resources- that is to say, a work force or/and cash to hire workers, rushed to clear land plots at the edge of Heng Brother's landholding to fix these areas as their land. They opened new plots, continuously grew annual crops and built wooden houses. The other ELC beneficiary, Chieng Ly, a Khmer-Chinese company, encountered organisational challenges and delays, such as securing adequate budget and machinery for land clearing or for developing rubber nurseries. These contingencies gave Malik villagers time to react and limit dispossession; like with Heng Brother, they could continue farming as the company was slow in expanding the planted area. In some places, the villagers were able to continue farming until 2012, and their efforts were rewarded: of the three villages studied, Malik is the one with the highest proportion of families (9o per cent) who had land measured in 2012. The measurement operation is not negligible, as the average area families had measured — and for which they later received a land certificate - was 4.63 ha. The Chieng Ly development was also challenged by Khmers, as explained by one of its managers, who complained about powerful 'Khmer land-grabbers' that the company is not able to chase out.

We thus have three sites, each with various dispossession dynamics of uneven magnitude: Pra Lai, where, despite the ELC-related, large land loss on paper, villagers are - overall—left with enough land to meet their basic needs; Trang, where the entire village lacks land to satisfy its basic needs; and an in-between situation in Malik. At all three sites, land acquisitions generated differentiation among families depending on their respective capacities to compensate for land loss by clearing other plots. The families who had a large enough workforce could rapidly compensate for the land they had lost; others 
could not or could only to a lesser extent. Differentiation increased further, as those who could clear land were also able to sell the wood thus gathered. This gave them the financial capital needed to pay workers for further clearing. Moreover, in a context in which state control over forest clearing and 'illegal' logging was intensifying, the families who had political and social capital could clear land and sell wood, whereas ordinary families were forbidden to do so and were at risk of having the wood they had gathered confiscated. The arrival of new landholders, companies, and in-migrants opened new avenues for access to productive capital. Representatives of communal authorities, who had eased the settlement of these newcomers, were the first to get access to the start-up package for rubber-that is, good quality rubber seedlings, fertilisers, and technical advice for planting. Meanwhile, the majority of the indigenous population could — at best—only find jobs clearing the lands of the new landholders.

\subsubsection{Livelihood Change}

For communities who did not know any limitation to access to land and forests other than the availability of the workforce needed to clear them, the foremost difference in current livelihood systems is the comparably limited natural areas they use. According to the survey conducted in 2013 in the three villages studied, for all villages almost two-thirds of the families (64 per cent) had less than 5 ha of land to farm, which is deemed the minimum area for meeting basic needs (with the current, ordinary cropping system including mostly rice, vegetables, cassava, and soya). The median land area per family is 3.9 ha and the mean is 5 ha. This is roughly about half the area that average families used to farm, including fallow areas, before the acceleration of land acquisitions a decade ago. The limitation in land available for farming is uneven across the three villages and within each village, as shown in Table 7.1. Land loss is more acute in Trang village, where half of the families have less than 2 ha each, whereas in Pra Lai and Malik villages this figure is 9.4 and 4.8 per cent, respectively. One-fifth (18.7 per cent) of Trang families reported being landless, compared to 6.2 and 2.4 per cent, respectively, in the two other villages. From our qualitative interviews, we did not find any indication that land areas were less abundant in Trang than in Pra Lai or Malik prior to the land acquisitions analysed above. The difference is explained mostly then by the purchases of land by Khmer migrants, who — so far-have not reached Pra Lai.

The reduction in the land indigenous populations can have access to has led first to an intensification of land use, typically farming the same plot more times and reducing fallow duration, until rice yield significantly declines. 
TABLE 7.1 Distribution of households by size (in ha) of land parcel owned (percentage of all surveyed households)

\begin{tabular}{|c|c|c|c|c|c|c|c|}
\hline & $<0.1$ ha & $0.1-1.9$ ha & $2-3.9$ ha & $4-5.9$ ha & $6-7.9$ ha & $8-9.9$ ha & $\geq 10$ ha \\
\hline \multicolumn{8}{|l|}{ Pra Lai } \\
\hline $\begin{array}{l}\text { Percentage of } \\
\text { households }\end{array}$ & $6.2 \%$ & $3.1 \%$ & $18.7 \%$ & $25 \%$ & $6.2 \%$ & $12.5 \%$ & $28.1 \%$ \\
\hline $\begin{array}{l}\text { Cumulative } \\
\text { percentage }\end{array}$ & & $9 \cdot 4 \%$ & $28.1 \%$ & $53.1 \%$ & $59 \cdot 4 \%$ & $71.9 \%$ & $100 \%$ \\
\hline Trang & & & & & & & \\
\hline $\begin{array}{l}\text { Percentage of } \\
\text { households }\end{array}$ & $18.7 \%$ & $31.2 \%$ & $31.2 \%$ & $0.0 \%$ & $0.0 \%$ & $6.2 \%$ & $12.5 \%$ \\
\hline $\begin{array}{l}\text { Cumulative } \\
\text { percentage }\end{array}$ & & $50 \%$ & $81.2 \%$ & $81.2 \%$ & $81.2 \%$ & $87.5 \%$ & $100 \%$ \\
\hline Malik & & & & & & & \\
\hline $\begin{array}{l}\text { Percentage of } \\
\text { households }\end{array}$ & $2.4 \%$ & $2.4 \%$ & $17.1 \%$ & $36.6 \%$ & $19.5 \%$ & $7 \cdot 3 \%$ & $14.6 \%$ \\
\hline $\begin{array}{l}\text { Cumulative } \\
\text { percentage }\end{array}$ & & $4.8 \%$ & $21.9 \%$ & $58.5 \%$ & $78.5 \%$ & $85.4 \%$ & $100 \%$ \\
\hline
\end{tabular}

SOURCE: SNIS PROJECT QUESTIONNAIRE-BASED SURVEY, AUGUST 2013.

Traditional 10-15 year-long fallow periods no longer exist; fallow land is at risk. A total of 63 per cent of respondents reported that they did not have any fallow area at the time they were interviewed; the proportion reaches 70 per cent among households who hold less than 6 ha, and 81 per cent for those who hold less than 4 ha. The intensification of land use is also related to the fact that families tend to be made up of an increasing number of people to feed, as there is no land left for the youth to open new fields. Furthermore, farming what is left of land is not always profitable: in Trang, we found cases where near-landless families explained they had not farmed the entire area they have access to because of soil exhaustion. They also explained that they had abandoned farming their land because the output was less than what they can expect from off-farm activities, although the availability of job opportunities is rather random.

A second transformation in cropping systems is a reinvestment in paddy rice for those who have access to low, wet land which had been relatively neglected 
TABLE 7.2 Distribution of households by size (in ha) of rubber land area (percentage of all surveyed households)

\begin{tabular}{llllllllll}
\hline & $<$ o.1ha & $\mathbf{0 . 1 - 1 . 9}$ ha & $\mathbf{2 - 3 . 9}$ ha & $4-5.9$ ha & $6-7.9$ ha & $8-9.9$ ha & $\geq 10$ ha & Total \\
\hline $\begin{array}{l}\text { Number of } \\
\text { households }\end{array}$ & 204 & 12 & 14 & 8 & 1 & 0 & 2 & 241 \\
$\begin{array}{l}\text { Percentage of } \\
\text { households }\end{array}$ & $84.6 \%$ & $5.0 \%$ & $5.8 \%$ & $3.3 \%$ & $0.4 \%$ & $0.0 \%$ & $0.8 \%$ & $100 \%$ \\
$\begin{array}{l}\text { Cumulative } \\
\text { percentage }\end{array}$ & $89.6 \%$ & $95.4 \%$ & $98.7 \%$ & $99.1 \%$ & $99.1 \%$ & $100 \%$ & \\
\end{tabular}

SOURCE: SNIS PROJECT QUESTIONNAIRE-BASED SURVEY, AUGUST 2013.

as farmers invested in cash crops. Of the total number of households, $5^{6}$ per cent grow paddy in low, wet land. A third transformation is the increasing share of farmed land dedicated to cassava, and to a lesser extent to soya beans, rather than to rice and associated vegetables. Cassava is grown by 82 per cent of the households, on a mean area of 1.98 ha per household, whereas soya is grown by 37 per cent of the households. Cassava has become the cornerstone of farming systems as it provides farmers' main income in the context of an increasing need for cash; cassava is also the main source of savings for capital expenditure (housing and transportation) and eventual investment into rubber. A fourth transformation is the plantation of rubber trees, rather than cashew nut trees, although there were only 15 per cent of the families who reported owning rubber trees.

Another major change explained by our interviewees consists in the reduction of the cattle that they own due to several reasons: families sell animals to raise much-needed cash; there is increasingly less space for grazing and people cannot spend the required time to walk their cattle; finally, owing to the limited space available, they fear the possible damages that the animals might make to rubber trees, and the fines or retaliations (especially in terms of animals killed) on the part of the companies. At the time of interview, seven households out of ten did not own one single buffalo and eight out of ten did not have a single cow.

Household members are increasingly searching for salaried employment in the various types of rubber plantations. New landholdings at first created jobs, to clear and prepare the areas to be planted and to take care of the plantations during their early years; then, the plantations needed fewer workers - mechanisation developed and companies hired workers with skills 
that indigenous people do not have. Also, job creation benefits migrants more than native populations: Khmer owners have made it very clear that they hire Khmer workers because native populations lack not only skills but also commitment - that is to say, they do not commit durably to their employers' companies as they must also pursue their own farming activities, whereas Khmer in-migrants work full-time and remain with their employers longer. Only 8.7 per cent of people reported having a regular salaried occupation. The overall process of rural development has certainly created petty opportunities in food processing (typically pealing cassava tubers), local trade, transportation services, etc., but most of these are taken up by in-migrants. Similar to the low proportion of households the members of which have regular salaried jobs, only 11 per cent of households reported members having non-farming occupations of their own, and they were almost exclusively non-native households. Out-migration is not an option for the inhabitants of Trang, Pra Lai, or Malik: only 3.7 per cent of families reported they have one member living outside the commune and 4.1 per cent reported that they receive remittances. While respondents lack acquaintances outside the area and do not know anyone living in cities, the need and the motivation - of the area's youth in particularfor leaving the village is strong, as illustrated by the number of interviewees who said that they would be ready to move, even when considering the risks they have heard of associated with migration.

Differentiation among families is increasing, in particular with respect to land area. When comparing change in land area between 2010 and 2013 with land area in 2013, we found that among the families who reported having less land in 2013 than in 2010, seven out of ten belong to the group with less than 6 ha of land, whereas three out of ten belong to the group holding more than $6 \mathrm{ha}$. The difference in land assets is even more acute between the native population and the newcomers, as shown in Table 7.3. Forty per cent of the native population report having less land, whereas the proportion is only 10.7 per cent

TABLE 7.3 Change in households'land assets between 2010 and 2013 (percentage of relevant population category)

\begin{tabular}{lccrr}
\hline & Less land & Same land & More land & Total \\
\hline Entire population & $32.6 \%$ & $56.1 \%$ & $11.3 \%$ & $100 \%$ \\
Native & $40.0 \%$ & $54.5 \%$ & $5.5 \%$ & $100 \%$ \\
Non-native & $10.7 \%$ & $60.7 \%$ & $28.6 \%$ & $100 \%$
\end{tabular}


for the non-native population. Similarly, 28 per cent of the non-native population have increased their land area over the period, whereas this figure is only 5 per cent in this case of the native population.

\subsection{Champasak}

\subsubsection{Local Context and Background}

After the failure of the first rubber plantation in Laos, established by the French in the southern province of Champasak in 1930, a few other public and private attempts at developing the crop were made during the 1990s (Manivong and Cramb, 2008; Baird, 2010). Yet, only recently has rubber become a widespread distinctive feature of the rural landscape. Through large land concessions granted by the central or provincial government, Vietnamese investors have revitalised rubber in Champasak, mainly in Bachiang and, to a lesser degree, Paksong districts ${ }^{5}$ (Schönweger et al., 2012). Both districts are located on the Bolaven Plateau-Bachiang in its western hillsides; Paksong in more altitudinal areas - a region predominantly inhabited by autochthonous Mon-Khmer ethno-linguistic groups (Goudineau, 2008; Baird, 2010) and also by non-native Lao-Tadai groups (Fortunel, 2007). These groups rely on semi-subsistence farming, most of which is carried out manually.

The villages studied-Thongpao, Huaytong, Lak Sip Kao (all in Bachiang), and Lak Sao Paet (in Paksong) - were founded shortly before or amid the us heavy bombardments that followed the escalation of the Laotian Civil War. ${ }^{6}$ Despite movements of people related to the war, collective memory stresses a time of plentiful land resources, with livelihoods tied to the cultivation of rice, coffee, vegetables, fruit, peanuts, and cardamom, and to the raising of livestock. After a brief and only feebly enforced period of collectivisation, ${ }^{7}$ farming continued as usual: '[in principle] families could clear as much as they wanted'8 under customary arrangements mediated by village chiefs or between families. Due to labour limitations, families usually cleared and farmed up to 5 ha. Social differentiation at the time was minimal; the founders of the village and party-appointed leaders, including war veterans, enjoyed more social prestige, but not necessarily larger productive assets. Households in possession of cattle and irrigated rice paddies were regarded as wealthier. Subsistence farming

5 In Paksong, land concessions for coffee outweigh those for rubber.

6 This war (1955-1975) was fought between the royalist government forces (backed by the Us) and the communist Pathet Lao (supported by North Vietnam).

7 Except for Lak Sip Kao's collectivisation (1976-89), other villages participated only loosely for 2-3 years.

8 Interview with village authorities, 26 February 2014. 
was practiced in rotational mixed-cropping systems with long fallow periods of a minimum of five years. In lower areas, paddies complemented rain-fed rice. Rivers and forests also provided a major source of nutrition (fish, wild game, NTFPS), especially in between the dry and wet periods (February-April), coinciding with the end of the coffee harvest and the start of a new rice farming cycle.

The Land and Forest Allocation Programme (LFA), implemented in the 199os, brought about a crucial change in people's modus vivendi. Aimed at distinguishing forest from other lands, the LFA was a nationwide programme that covered processes from mapping and zoning village land to issuing temporary use certificates for farmland and degraded forest (Fujita and Phanvilay, 2008). It was coupled with a ban on rotational cultivation and with other povertyreduction plans, often entailing the relocation of villages to focal areas-close to roads, markets, schools, and clinics (Evrard and Goudineau, 2004). Although the cases studied here did not involve relocation, the imposition of different land zones both created confusion and limited people's access to resources. Government and development aid agencies encouraged intensive cash-crop agriculture over 'unproductive' fallow land. Paksong, with a small coffee industry fruitfully initiated by the French in the 1920 (but interrupted by wars), saw a boom in coffee production (Sallée and Tulet, 2010). Coffee (mostly of the robusta variety) has since become the main source of income in Lak Sao Paet. Without proper, elevated soils for coffee and without sufficient attempts at developing higher-value cash crops, the usual rainy-season crops for sale in Bachiang remain corn, peanuts, and fruit, in reduced rotational systems. Cassava is a recent addition, sold in the dry season. Households in Lak Sao Paet and Lak Sip Kao have recently diversified incomes by turning to, or increasing a long-established small trade in, artisanal baskets and brooms, and machetes, respectively.

On the ground, since the LFA was barely enforced at all by the relevant authorities, rotational farming and NTFP collection had somehow persisted prior to the granting of concessions. Weaknesses in the LFA's implementation also meant that the step of handling land use certificates went largely missing in the studied sites, especially for fallow land, which would later facilitate the granting of concessions.

\subsubsection{Land Concessions}

Between 2004 and 2006, up to 30 per cent of Bachiang district land (of a total of 78,676 ha) featured in announced concession plans for three Vietnamese rubber companies: Viet-Lao Joint Stock Rubber, Yao Tieng Rubber Partnership, and Dak Lak Rubber (Srikham, 2010). Although the companies started clearing 
land at the time, the total concession area after approval, as registered by the National Land Management Authority (NLMA, 2009-2011), represents a lower, yet still significant, share of the district land (18.4 per cent). Yao Tieng was granted a total area of 1,489 ha in Bachiang, and 333 ha in Paksong; VietLao was granted a concession for 10,316 ha, and Dak Lak for 2,677 ha, both in Bachiang (NLMA, 2009-2011). Concession areas coincided with the locations of the studied villages (and many others) for reasons of soil suitability, land availability, and relatively easy access. ${ }^{9}$ Lak Sip Kao is the closest to the provincial capital of Pakse (19 km away); Thongpao is the farthest (circa $70 \mathrm{~km}$ away). Given its location in a less elevated area, adequate for the rubber crop, Lak Sao Paet $(28 \mathrm{~km}$ from Pakse) is currently the only village in Paksong with a rubber plantation, operated by Yao Tieng since 2008 (Department of Agriculture and Forestry, 2013). Table 7.4 shows the hectares cleared on each site per company, relative to the village size beforehand. Concession areas span from 34 to 95 per cent of total village area cleared - with 89 per cent as the average for Bachiang villages. As rubber was rapidly planted, companies had reached the tapping phase by 2013 .

TABLE 7.4 Magnitude of land concessions in four selected villages

\begin{tabular}{|c|c|c|c|c|}
\hline Village & Company & $\begin{array}{l}\text { Village size prior } \\
\text { to concession } \\
\text { (ha) }\end{array}$ & $\begin{array}{l}\text { Area cleared } \\
\text { by concession } \\
\text { (ha) }\end{array}$ & $\begin{array}{l}\text { Percentage } \\
\text { of village } \\
\text { area cleared }\end{array}$ \\
\hline Thongpao $^{10}$ & Yao Tieng & 400 & 273 & $68 \%$ \\
\hline Huaytong, & Viet-Lao & 144 & 68 & $47 \%$ \\
\hline Lak Sip Kao ${ }^{11}$ & Dak-Lak / Yao Tieng & 563 & 536 & $95 \%$ \\
\hline Lak Sao Paet & Yao Tieng & 717 & 245 & $34 \%$ \\
\hline
\end{tabular}

SOURCE: FIELD RESEARCH BY SENTIES PORTILLA, 2012-13.

9 Interview with district authorities, 15 July 2013.

10 According to an anonymous source, Dak Lak's concession also contained Thongpao, but village records of 2006 only register Yao Tieng. Discussions with two village chiefs led the researchers to conclude that the land in question was part of Thongpao, but had been lost to a neighbouring village following a border dispute in 2005- and then granted to Dak Lak.

11 The area cleared is for two companies (Dak Lak and Yao Tieng); areas for each were not specified. 
The way land concessions unfolded on the ground is described in similar terms across all the villages. The central or provincial government had planned and approved land allocations for the companies without previous consultations with village authorities and local populations. Villagers were told that the companies would adequately compensate them. The base average payment for one hectare was 1 million Laotian kip (LAK), ${ }^{12}$ which was not enough to cover the purchase of the rice required for two months by the average (eightmember) family interviewed. With rare exceptions, families believed they could not (or should not) oppose the concessions, especially because higher authorities had taken those decisions. Most villagers felt pressured by the fact that district officials organised village meetings to announce the approval of grants by provincial or central level authorities (showing papers not necessarily signed yet), and did so in the presence of company representatives and, in some cases, the district police. Village chiefs did not have any say in the investment plans and decision-making process, but most served as facilitators of the concessions. When some families were reluctant to agree, village chiefs warned them that the company would take their land anyway without providing any compensation.

The outcomes of such dispossession vary across and within the sites due to the magnitude of land loss, the new actors drawn into the land rush, and livelihood assets and trajectories up until the concessions were granted. Lak Sip Kao has suffered the most serious loss, as 95 per cent of its land has been absorbed by two different concessions. An estimated 80 per cent of the total 270 households in Lak Sip Kao had in between $2-5$ ha of land. Most of the families interviewed in this group were left with none, despite their attempts to avoid their land being cleared by planting fruit trees on their 'idle' swidden land. At the other end of the spectrum lies Lak Sao Paet, where, since the cultivation of coffee entails more permanent uses of land, some coffee smallholders were able to demonstrate that land was 'in use'-as opposed to being kept fallow, in which case it was given away in the form of concessions with no compensation being received in return. Notwithstanding these differences, it was found that the majority of households in all villages experienced serious land loss, as illustrated by Table 7.5 below.

A comparison of the situations prior to and after companies planted rubber indicates that the average size of household farmland for all villages combined fell from 3.96 to 1.17 hectares. Households who had $3-5$ ha prior to concessions being granted were left-post-concessions - with around 1-2 ha of farming

12 USD 125 at current conversion rate (May 2015). Conversion rate around the time when the concessions were granted was USD 1 = LAK 9,000. 
TABLE 7.5 Average household farmland size in four selected villages (2003 and 2013, in ha)

\begin{tabular}{lll}
\hline Village & $\begin{array}{l}\text { Average household land size } \\
\text { in } 2003 \text { (ha) }\end{array}$ & $\begin{array}{l}\text { Average household land size } \\
\text { in } 2013 \text { (ha) }\end{array}$ \\
\hline Thongpao & 3.11 & 0.85 \\
Huaytong & 5.24 & 0.66 \\
Lak Sip Kao & 3 & 0.75 \\
Lak Sao Paet & 4.25 & 2.45 \\
Total average & 3.96 & 1.17 \\
\hline
\end{tabular}

SOURCE: FIELD RESEARCH BY SENTIES PORTILLA, 2012-13.

land, usually paddy or coffee plots. This is true for approximately 70 per cent of households of all the studied villages combined. Consequently, swidden agriculture is—-for the majority—no longer possible, in a context where most villagers were rotational farmers. None of the families interviewed had temporary land certificates for farmland, which the LFA had meant to provide. This supported the argument that villagers' 'idle' swidden land was to become the property of the state, a transfer for which no compensation would be provided. Some certificates had been given to villagers in Lak Sip Kao, Huaytong, and Lak Sao Paet. These, however, only covered land close to the main road, including houses, paddy fields, and fruit or coffee trees; but not larger, more distant plots of farming land..$^{13}$ District and village authorities claimed that no such certificates had (yet) been provided in Thongpao. In Lak Sao Paet, there were cases in which villagers approached the company themselves to sell some of their previously 'certified' plots; sales for which they had allegedly received a higher price-compared to the average base payment on other sites, the difference was not significant.

In addition to the Vietnamese plantations, a few cases were encountered in which provincial government officials hold concessions. In Huaytong, 2.2 ha of the first colonial plantation - presumably the same plantation that a stateowned company later revamped in the 199os - was recently granted to a public official from Pakse. Employees have been brought in from outside the area,

13 These findings confirm a previous study in Lak Sip Kao (Hall et al., 2011). Respondents from our study remained unclear as to whether these certificates were land titles within the framework of a titling programme, the second phase of which (in rural areas) began in 2003 . 
allegedly because the local inhabitants are already occupied at the Viet-Lao plantation or with their own farming activities. In Lak Sip Kao, other civil servants have set up smallholdings (figures unspecified) growing rubber, which has required buying whatever land is left from the local inhabitants. These cases of land acquisition by Lao nationals seem, however, to be operating with more ease because locals think of these investors primarily as 'government people', against whom any open resistance is unthinkable.

Margin for manoeuvre or for avoiding major losses is limited to very few households. Farmers at large, including those with permanent land use rights, had greater chances of keeping some or all of their land if they had acquaintances in the government and/or some information about their land rights under statutory land laws. There were also exceptional cases, seemingly without the aforementioned advantages, in which households negotiated or opposed their dispossession. In Huaytong, a villager successfully pushed for a higher price per hectare, even though a Viet-Lao representative threatened to have provincial officials sent to 're-educate' him. In Lak Sao Paet, an elderly widow refused altogether to sell her land to Yao Tieng because their proposed payment was not enough to make up for her loss in crops. She threatened to cut down their rubber trees if the dispossession went ahead. In these cases of seemingly limited or no dispossession, other losses come into play.

The proximity of the rubber plantations to local farming land (a range of $0.5^{-3} \mathrm{~km}$ ) has created a scenario in which households who have kept enough land prefer not to carry on with shifting cultivation due to fears that nearby rubber trees will catch fire when those households' own fields are burned. In addition to farming land loss and disruption of traditional cultivation, there has been a reduction in forest land and watercourses have been polluted. This means that the enclosure of plantations and their proximity to villagers' farm lands have also prevented villagers from continuing to pursue other livelihoods, such as cattle grazing, fishing, hunting, and collecting NTFPs. Some families have observed reductions in fish populations in nearby rivers and blamed this on the use of chemicals on the plantations, chemicals that have created health problems for workers.

\subsubsection{Livelihood Change}

Over the past seven years, households have substantially decreased family farming activities, which were their main occupation until the onset of the concessions, and have instead increased their salaried activities. Some now devote their time entirely to wage labour, a trend that is more pronounced in Bachiang. For households with more than 1 ha of land left, (now insufficient) farming output is complemented with paid work, typically at the rubber 
plantations. These households have continued with the cultivation of traditional cash crops (corn, peanuts, coffee), and they are increasingly planting cassava, especially in Bachiang. In the initial two years of rubber plantation, Bachiang families could continue planting peanuts and corn in between the young rubber trees, but as the trees have now grown, people have turned to their remaining plots, where rotation is very limited. In Lak Sao Paet, in Paksong, most households have continued with coffee cultivation, but reportedly more are now engaged in basket-and broom-making, or in selling the raw materials for these activities to intermediaries who then sell these for a higher price in Pakse or Chong-Mek, the border checkpoint with Thailand. While old cash crops, and newer ones such as cassava, have provided incomes to meet growing needs, land is at risk of exhaustion when it is cultivated without rotation. This intensification is also found in the case of upland rice, where fallow duration has been shortened to a maximum of three years.

For families with less than 1 ha, farming only takes place if family members cannot find anything (salaried) else to do. There are a few instances in Thongpao and Huaytong where those who were landless prior to the concessions were already salaried workers for other landed families, mainly outside their villages. Now they also work at the plantations.

The availability of work at the plantations has, however, fluctuated over time and cannot be taken for granted. In the early years, companies were reluctant to engage local inhabitants because they were perceived as 'unreliable sompao [ethnic] people', who are 'difficult to work with because they do not commit for long.'14 Companies brought in labour from outside, including Vietnamese workers. In some cases, this reluctance was mutual, as villagers mentioned not wanting to work for the companies either out of expressed feelings of resentment, or because they believed they could not compete with the Vietnamese, who are said to be 'better and faster' at the tasks. In Huaytong, the village authorities reported that in 2006 Viet-Lao only hired ten people from the village (i.e. 4 per cent of the population). Eventually, the companies had to engage more local labour due to the amount of clearing required, but when those tasks were complete less labour was needed. Hiring experienced another resurgence when the rubber tapping started.

Jobs at the plantations are mostly for young people; 'old' people (>40 years old) are often considered ineligible. Working conditions and salaries were systematically reported to not match people's expectations and household needs. Whereas male rubber tappers earn, on average, LAK 1 million per month across all studied sites, female tappers reported an average wage of LAK 
TABLE 7.6 Main livelihood activities in four selected villages (2003 and 2013)

\begin{tabular}{|c|c|c|}
\hline Village & 2003 & 2013 \\
\hline Thongpao & $\begin{array}{l}\text { - Agriculture } \\
\text { a) Rain-fed rice, for consumption } \\
\text { b) Peanuts and corn in swidden } \\
\text { systems, as cash crops }\end{array}$ & $\begin{array}{l}\text { - Salaried work } \\
\text { a) Rubber plantations } \\
\text { b) For other families in village } \\
\text { or nearby } \\
\text { - Agriculture } \\
\text { a) Remaining farmland turned } \\
\text { to cassava production }\end{array}$ \\
\hline Huaytong & $\begin{array}{l}\text { - Agriculture } \\
\text { a) Irrigated and rain-fed rice, for } \\
\text { consumption } \\
\text { b) Fruit trees, cassava, and coffee in } \\
\text { permanent land, for consumption }\end{array}$ & $\begin{array}{l}\text { - Salaried work } \\
\text { a) Rubber plantations } \\
\text { b) Factory and domestic work } \\
\text { outside village } \\
\text { - Agriculture } \\
\text { Fruit trees, coffee, and cassava }\end{array}$ \\
\hline Lak Sip Kao & $\begin{array}{l}\text { - Agriculture } \\
\text { a) Irrigated and rain-fed rice, } \\
\text { for consumption } \\
\text { b) Fruit trees and coffee in } \\
\text { permanent land, as cash crops } \\
\text { - } \text { Machete-making }\end{array}$ & $\begin{array}{l}\text { - Salaried work } \\
\text { a) Rubber plantations } \\
\text { b) Construction work } \\
\text { c) For other families outside } \\
\text { village } \\
\text { - Machete-making }\end{array}$ \\
\hline Lak Sao Paet & $\begin{array}{l}\text { - Agriculture } \\
\text { a) Coffee (mainly robusta) in } \\
\text { permanent and swidden systems, } \\
\text { as a cash crop } \\
\text { - } \text { Basket- and broom-making }\end{array}$ & $\begin{array}{l}\text { - Agriculture } \\
\text { a) Coffee and fruit trees } \\
\text { - Salaried work } \\
\text { a) Rubber plantations } \\
\text { b) Coffee plantations } \\
\text { - Basket- and broom-making }\end{array}$ \\
\hline
\end{tabular}

SOURCE: FIELD RESEARCH BY SENTIES PORTILLA, 2012-13. 
700,000 . Other tasks, such as clearing, provide lower (daily) wages..$^{15}$ The most frequently cited reason for gender-based wage differences was 'you get paid depending on how much rubber you tap', followed by 'the boss in your team decides how much you get'.

In their search for jobs, some villagers have had to go further away from their place of residence. Such mobility, which is temporary in most cases, depends on networks outside the area, which are developed in all the studied villages, but to a lesser degree in Thongpao. For the few young people in Thongpao who have experienced temporary work outside their home village, having a rubber plantation located in the area has meant that they 'can now choose to stay', even though they are aware of the poor employment conditions and their limited future prospects as small landholders. Across villages there is a general perception among the young that having cash is relatively better than having land that produces only food for the household. Cash, and its perceived regular availability (on-site) with the coming of the plantations, can provide young villagers with their three main desires: 'you can buy a motorbike', 'you can have a better [concrete] house', and 'it gets you clothes and nice things [consumer goods]'. Although the majority of the young acknowledged that cash could also be obtained from family farming, they highlighted various constraints: a lack of labour input; a lack of necessary capital and/or skills in their households to have a good, copious harvest; and —above all—that land was becoming scarcer. Another constraint mentioned was a lack of the knowledge necessary to market their produce at a higher price. A few of them-chiefly those who had experienced more years of schooling outside their village, but had 'no money to continue'-mentioned they were 'not so interested in farming; we just do it, we have no choice'. For the middle-aged and older villagers, things are not worse or better: 'Before, we had land and we had food; now we have almost no land but we can find money to buy food.'

In Lak Sip Kao, where households have so far coped by combining salaried employment (at the plantations or elsewhere) with machete-making, the situation is now uncertain because possible village relocation plans for a stadium construction are underway. According to village authorities, at the time of latest interview (21 January 2014), the project's approval was being discussed in Vientiane.

Growing rubber, although appealing, remains impossible due to a lack of land and start-up capital and/or know-how. Only one interviewed family, in Huaytong, has invested in rubber. Since the household head is a war veteran and an influential figure in the village, particularly with regard to land

15 Interviews, 16 July 2013, and group discussion, 29 January 2014. 
issues, he was able to retain some of his land. After family members acquired knowledge of rubber by working for Viet-Lao, they bought rubber trees from the company and planted them in two hectares. The family is confident and enthusiastic about the potential of their small rubber plantation, which will turn profitable in 2016: 'By then, others will see [the benefit] and perhaps start doing the same.'

Our case studies present several points of resemblance. In contrast to depictions of poverty and vulnerability as endemic and intrinsic to traditional cultivation systems, we found that local populations' vulnerability prior to the mid-200os was mostly generated by public policies, which pertain mainly to the population's displacement for Ratanakiri, Cambodia, and to restrictions on access to and use of farmland in Champasak, Laos. In both countries, the agrarian transition was marked by the introduction of cash crops prior to the wave of land acquisitions, coupled with more radical changes driven by the arrival of large-scale rubber plantations, which are similar in size in our case studies-4,147 ha on average for Ratanakiri; in Champasak, an average of 4,938 ha.

In both areas, the acceleration of land deals and the development of new crops - rubber but also cassava - has greatly changed the economic environment in which indigenous populations lead their lives and experience their social systems. Rural interconnectedness has increased thanks to new and better-maintained roads and because most of the families nowadays own at least one motorcycle. Secondary towns, district-centres, rural marketplaces, and crossroads have grown rapidly. The supply of agricultural inputs, tools, construction materials, medicine, consumption goods, etc. has increased. Small retail shops have opened in villages-people who travel back and forth on motorcycles supplying them regularly — and the range of goods has diversified. In addition, travelling sellers make tours of the villages, where they sell meat, fish, vegetables, etc. However, urban and market development are not systematically synonymous with betterment for the bulk of the population. Some of the foods that these travelling sellers offer for sale in the villages are items that villagers used to produce or collect by themselves, and that they must now pay for, as these products are now produced less and because populations are increasingly busy with other off-farm tasks. Trade and markets have developed, but farmers sell their harvests mostly at home. Although sale prices are higher a few kilometres outside villages, producers do not know how to operate in those marketplaces. 
The major difference between Champasak and Ratanakiri lies in the magnitude of land loss and the consequent importance of non-farming activities to new livelihoods. Land loss in Champasak has overall been more severe than in Ratanakiri. Yet, our research in Cambodia shows that 'the bigger, the more severe' is a premise that does not always stand. In Ratanakiri, the pace of development of the (large) ELCs left some time and space for former users to respond, whereas no such time was given to the population of Champasak. Several factors can explain this difference, including the proximity to/distance from, and overlap with, areas that were previously used. In Ratanakiri companies did not have sufficient physical capital to plant the large granted areas. A second major difference is the involvement of a wider range of new actors in Ratanakiri, including medium-sized Khmer companies operating outside the frame of ELCs and numerous in-migrants who settled in the villages, all of whom contributed significantly to the process of land acquisitions. Incoming migration in Champasak villages, in relation to salaried work at the rubber plantations, was found to be much lower and more temporary. Champasak families have found more, although intermittent, job opportunities in rubber plantations than their peers in Ratanakiri, who suffer from the tough competition of Khmer in-migrants.

We also observed differences in populations' attitudes towards the new holders of land. In Ratanakiri, populations dared to respond to and in some cases to contest central government-signed ELCs, whereas in Champasak villagers rarely contested upper-level decisions, and even less so challenged acquisitions by public officials. This may reflect the fact that the state in Laos has a tighter and more effective control over its populations than does the state in Cambodia - whether this is real or merely perceived as such by those who are governed. Another marked difference was found in Ratanakiri where local populations express a fear of Khmer landowners, who they say are highranking and well-connected people with unlimited power, which is not the case with foreign-held land concessions. Local populations responses are also telling regarding the subjective meanings underlying power relations, as illustrated by the Ratanakiri population, which expresses having lower capabilities compared to the Khmer, who they say they are 'more clever'. Similar expressions from villagers in Champasak (non-Lao ethnic and Lao alike) were also heard regarding the Vietnamese.

We can thus distinguish two levels of dispossession that we will hereafter label as 'partial' and 'severe'. As dispossession levels are uneven across households within a single village, we then draw on a typology of the transformation of household livelihoods across our cases. 
Partial dispossession, as found to be predominant in Pra Lai and Malik (Cambodia) and Lak Sao Paet (Laos), comprises situations in which villages were left with enough land for the majority of families to-so far-satisfy their basic needs from farming. Partial also means that livelihoods remain centred around family-based activities, although families are increasingly in search for salaried jobs. The magnitude of partial dispossession is tied to the capacity of local populations to make up for their land loss by clearing other areas, to negotiate with companies the retention of some of their (the populations') land, to get incorporated into rubber companies, or to receive monetary or non-monetary compensation. Apart from the size of land loss relative to the total area previously farmed by the local population, some cases of partial dispossession are related to a slower pace of development achieved by companies, and the consequent opportunity for the local population to anticipate and respond to land acquisitions. Thus, the transformation of partial dispossession into severe dispossession might just be a matter of time; the time it will take for investors to plant the full holding they were granted.

Severe dispossession, as observed in Trang and the three villages in Bachiang, depicts situations in which access to land and other natural resources is not enough to satisfy basic needs. Dispossession is severe particularly for swidden land, as both national governments concerned have facilitated the granting of land areas left fallow, with the argument that those areas were 'not used' or were 'state land'. Using the same argument, swidden plots were frequently not eligible for any type of compensation. Severity relates to the size of and a faster pace of plantation development; to people's powerlessness or perceptions of powerlessness in reacting to dispossession, particularly vis-à-vis certain types of investors or authority levels granting the concessions; and to the derisory amount of compensation, if compensation is provided at all. In some cases, severe dispossession also relates to the combination of large-scale land deals with a wave of small-scale acquisitions by in-migrants or public officials.

The typology of livelihood transformations reflects (1) how households were affected by and could respond to the politics of dispossession, (2) the main transformation of their economic activities over the last five to seven years, and (3) how they have managed, or not, to engage in the rubber boom.

A first group, which mostly includes village elites and their close relatives, has managed to retain some land or avoid being dispossessed altogether by orienting investors far enough away from their land. This represents around 2 per cent of households in Champasak and 4 per cent in Ratanakiri. Thanks to their status and power in their respective villages, they could easily compensate for any loss by obtaining access to other land. As they themselves often 
facilitated the land acquisitions, their acquaintance with investors enabled them to obtain access to inputs (seedlings) and/or technical advice to develop rubber plantations of their own on areas ranging from 2 to 10 ha. Only one case of a member of a village elite who planted rubber was documented in Champasak. This group also includes some of the oldest and well-off in-migrants.

A second group has thrived on the wave of land acquisitions and rubber boom-induced local development. It includes shop owners, traders, and households providing services such as transport, restaurant, repair work, brokerage, worker recruitment, and money lending. In Champasak, this group does not exceed 10 per cent of households of all the studied sites combined. In Ratanakiri, this group represents 7 per cent of the sample; members of the group are mostly outsiders to the places in which they have settled and established their business, and some of them invested in rubber at a time when land was still cheap, and they today possess plantations similar in size to those of the first group.

For the third group, farming activities have remained at the core of their livelihoods; farming-based livelihoods include an increasing share of land dedicated to cash crops, cassava and fruit trees, and a little rubber (1-2 ha). In this group, which accounts for 12 per cent of the total population surveyed in Ratanakiri, households have engaged in rubber through their own investments; only one such case was encountered in southern Laos. The engagement process has been slow or came later than for the two previous groups, as these households did not possess the necessary start-up capital and were not acquainted with the rubber companies. We cannot predict if these households will manage to turn their investment into profitable cropping systems, as the trees are not productive yet. So far, they have not had to work for others, or only occasionally.

For the fourth group, livelihood transformation is marked by an increasing share of salaried work - or petty commodity production for a few-as a proportion of their total income. They have become part-time farmers who do not have the capacity to engage in rubber. Their best achievement lies in finding more regular salaried jobs and possibly semi-skilled better-paid ones. Their prospects at home are much constrained by in-migrant workers; and their future elsewhere depends much on the social networks needed to facilitate migration. This group represents around 49 and 75 per cent of the totals, respectively, in Ratanakiri and Champasak.

A last group consists of rural workers for whom farming is practiced only when there is nothing else to do. In Champasak, this situation is reflected in an estimated 13 per cent of households, all studied sites combined. In Ratanakiri, 
28 per cent of households belong to this group. Salaried work has become the pillar of their livelihoods. Engagement in rubber was never an option. The existence of this group relates to severe cases of dispossession, where households sold too much of their land at an early stage, an occurrence in Ratanakiri, or to households that had large plots of swidden land falling in concession areas, as was the case in Champasak. In Ratanakiri, this group also includes in-migrants who have not yet acquired land and who came in search for work. Although regular jobs are rare, selling labour has become a more rational pursuit than farming. As job opportunities are not sufficient at home, out-migration of one or several household members tends to increase. Those who are not capable of migrating are left with limited choices, including 'desperate' sales of their remaining land assets.

\section{$5 \quad$ Conclusion}

In the seven villages that feature in this chapter, an agrarian transition from dominant subsistence-oriented swidden forms of agriculture had started prior to the acceleration of land acquisitions. However, as local government only loosely implemented public policies, and the development of cash crops for outside markets remained limited, the 'powers' of regulation and the market (Hall et al., 2011) were not strong enough to include these communities in the market economy. Yet, those public policies eroded the former agrarian system and thus paved the way for an 'insecure boom' (Hall, 2011, 3).

The power and pace of transition changed from the mid-20oos. The effectiveness of regulation increased because local governments were involved in its implementation process; furthermore, they contributed to its legitimation or rather its acceptance by local populations. At the same time, the power of the market increased: the booming demand for rubber, stronger than for any previous crop, made it more profitable for local government representatives to comply with central government strategy; it also convinced smallholders that rubber could be profitable. The transition strengthened further, as small landholders themselves became 'agents' of land transactions, with opportunistic village elites - in some cases-becoming agents of land grabbing within their own communities.

Despite substantial land acquisitions by outsiders, most local populations have until now managed to keep some land and to maintain farming activities for themselves. However, this state of affairs is bound to change at some point as large-scale companies are increasing their planted acreage and medium-scale companies are pursuing their search for surrounding areas to 
expand, and as the flow of in-migrants, in the case of Ratanakiri, is continuing. Furthermore, in response to the reduction in land available, families have intensified their cropping systems - of cassava in particular-in ways that might not be sustainable.

Beyond the reduction and depletion of those natural resources that are left to local populations, the majority are cornered by a socio-economic environment that increases their need for cash, while their former household farming-based livelihoods are not providing enough of a livelihood anymore, and rubber remains out of reach. In reference to the agrarian transition as described by Rigg et al. (2012), our cases show some major nuances. First, at the provincial level, the increasing share of non-farming activities is found in urbanising areas, market places, and along the main transportation networks; but for native populations the process is not advanced, despite their need and wish to get out of farming solely. Second, the process of 'delocalisation of life and living' is reflected in the shift of spaces created by land acquisitions, but the 'mobility' of native populations is confined to within the vicinity of their villages. Third, a dis-embedding of households and families is occurring, but not so much because of social and economic relations being 'stretched across space', but rather because of the development of individual interests, notably among the youth of the areas in question. Last, the dissociation of the villagecommunity is strong, as illustrated by the uneven opportunities brought about by newcomers and the opportunistic behaviour of village elites.

Family farming is not lagging behind; it is losing ground, as illustrated by land sales that are no longer even a short-term cash opportunity, but fall more and more into the category of 'desperate' sales to cover existing deficits. As opportunities to diversify economic activity remain insufficient, people will have to turn to the diversification of localities; out-migration is likely to become one of the key features of this agrarian transition.

Needless to say, a political commitment from the two national governments concerned to seriously and substantially reassess their development strategies in light of these consequences is urgent, and not simply a matter of procedural design or wishful, responsible thinking on the part of investors. The usual recommendation of prior informed consultations about land deals has not only_in our cases-become outdated, its presumed effectiveness for future investments remains more than uncertain in the light of current development drives. Furthermore, we cannot expect much from the Voluntary Guidelines for responsible investments, ${ }^{16}$ as investors on the ground have no incentive to abide by such guidelines, and nor will they feel under any pressure to harm their business with such instruments.

16 http://www.fao.org/3/a-au866e.pdf (accessed on 26 May 2015). 
There are indeed other remarkable issues that people are facing on a daily basis for which a broad palette of interrelated human rights instruments could be called upon for action. These include the right to food, the right to water, and the right to a livelihood. Nevertheless, international governance mechanisms will remain ineffective if they have no links or outreach to civil society organisations on the ground. In both countries studied in the context of this chapter, such organisations are few and often only mildly familiar with the work of global governance structures, and their intervention capacity is rather limited when compared to the magnitude of continuing land acquisitions.

Beside a structural policy change that would be needed to halt an agrarian transition that is undermining the livelihoods of the majority, it is also important to take into account that the process of losing ground has also been accompanied by a process of dislocation/disruption of family-based livelihoods. In such a situation, younger generations, which have-or can expect to secure-some autonomy by obtaining salaried employment, are considering moving away as they are faced with limited options at home, notably a lack of land for the foreseeable future. Moreover, having a salaried job has-locallybecome a perceived way of 'moving forward' or 'improving oneself'. Since such a direction 'forwards' is already leading some, and is very likely to lead many more, into exploitative situations, development practitioners should complement their advocacy of land rights, land tenure security, and access to information with assessments of capabilities and learning needs, in terms of vocational training, in a number of areas for which these populations express an interest; agriculture remaining one of them.

In Cambodia, salaried employment is developing with the rubber boomtapping rubber for instance-but indigenous peoples cannot access it because they lack the necessary skills. Even the indigenous elites hire Khmer in-migrants to tap their trees. In Laos, there is growing interest in pursuing the benefits from farming products and other activities that, for some years, have been practiced in parallel to household farming (e.g. basket-making and machete-making), and in newer activities such as mechanised textile sewing and hairdressing, particularly among the country's youth. Therefore, training programmes to support the development of such activities and the marketing of agricultural and non-agricultural products and services should be encouraged. Further, for the growing number of people who are in search of work outside their villages, vocational training could also make a great difference. In addition, awareness raising and legal advice should be provided regarding the risks associated with migration.

Although we do not take the socio-economic transformation described in this chapter as given and irreversible - and therefore we do not intend, by any means, to accept it - we do recognise that, while waiting for solutions to its 
structural causes, whose search, we hope, will no longer be delayed, we need to address the negative consequences of this transformation currently affecting local populations.

\section{References}

Baird, I. (2011) 'Turning Land into Capital, Turning People into Labour: Primitive Accumulation and the Arrival of Large-Scale Economic Land Concessions in the Lao People's Democratic Republic', New Proposals: Journal of Marxism and Interdisciplinary Inquiry, 5(1), pp. 10-26, http://ojs.library.ubc.ca/index.php/ newproposals/article/viewFile/2264/2265 (accessed on 23 April 2015).

- (2010) 'Land, Rubber and People: Rapid Agrarian Change and Responses in Southern Laos', Journal of Lao Studies, 1(1), pp. 1-47, http://lad.nafri.org.la/ fulltext/2042-0.pdf (accessed on 23 April 2015).

Bakker, L.G.H., G. Noteboom and A. Rutten (2010) 'Localities of Value. "Ambiguous Access to Land and Water in Southeast Asia"', Asian Journal of Social Science, 38(2), pp. 167-171, DOI: 10.1163/156853110X490872.

Barney, K. (2007) Power, Progress and Impoverishment: Plantations, Hydropower, Ecological Change and Community Transformation in Hinboun District, Lao PDR (Toronto and Washington, D.C.: YCAR Papers/Rights and Resources Initiative), http://www.cifor.org/publications/pdf_files/books/bbarney0701.pdf (accessed on 26 May 2015).

Borras Jr., S.M., and J.C. Franco (2012) 'Global Land Grabbing and Trajectories of Agrarian Change: A Preliminary Analysis', Journal of Agrarian Change, 12(1), pp. 34-59, DOI: 10.1111/j.1471-0366.2011.00339.x.

Bourdier, F. (2009) 'When the Margins Turn One's Step Toward an Object of Desir: Segregation and Exclusion of Indigenous Peoples in Northeast Cambodia', in Hammer, P.J. and M. Khmersiksa (eds.) Living on the Margins: Minorities and Borderlines in Cambodia and Southeast Asia (Phnom Penh: Center for Khmer Studies) pp. 177-185.

CDRI (Cambodia Development Research Institute) (2009) Agricultural Trade in the Greater Mekong Sub-Region. Synthesis of the Case Studies on Cassava and Rubber Production and Trade in GMs Countries, CDRI Working Paper Series No. 46 (Phnom Penh: CDRI), http://www.cdri.org.kh/webdata/download/wp/wp46e.pdf (accessed on 23 April 2015).

Cotula, L. (2013) The Great African Land Grab?: Agricultural Investments and the Global Food System (London and New York: Zed Books).

Delarue, J. (2011) Thailand: The World's Leading Exporter of Natural Rubber Owing to its Smallholders, Working Paper No. 96 (Paris: Agence Française de Développement), 
http://www.afd.fr/webdav/site/afd/shared/PUBLICATIONS/RECHERCHE/ Scientifiques/Documents-de-travail/og6-document-travail-VA.pdf (accessed on 23 April 2015).

Department of Agriculture and Forestry (2013) Information of Lease and Concession of Government Land to Private Entities, Foreign and Domestic Companies in 2012-2013 in Paksong District (Paksong District Office).

Diana, A. (2008) Navigating the Way through the Market: A First Assessment of Contract Farming in Luang Namtha (Vientiane: Deutsche Gesellschaft für Technische Zusammenarbeit, GTz) http://rightslinklao.org/wp-content/uploads/downloads/ 2014/05/Navigating-the-Way-through-the-Market-A-First-Assessment-of-ContractFarming-in-Luang-Namtha.pdf (accessed on 23 April 2015).

Edelman, M., C. Oya and S.M. Borras Jr. (2013) ‘Global Land Grabs: Historical Processes, Theoretical and Methodological Implications and Current Trajectories', Third World Quarterly, 34(9), pp. 1517-1531, DOI: 10.1080/01436597.2013.850190.

Evrard, O. and Y. Goudineau (2004) 'Planned Resettlement, Unexpected Migration and Cultural Trauma in Laos', Development and Change, 35(5), pp. 937-962, DOI: 10.1111/j.1467-7660.2004.00387.x.

Fortunel, F. (2014) 'Kampong Cham et Ratanakiri, regards croisés sur l'évolution des grandes plantations cambodgiennes', in Fortunel, F. and C. Gironde (eds.) L'Or Blanc, Petits et grands planteurs face au "boom" de l'hévéaculture (Viêt-nam-Cambodge) (Bangkok: Institut de Recherche sur l'Asie du Sud-Est Contemporaine) pp. 123-142, http://www.irasec.com/ouvrage113 (accessed on 23 April 2015).

- (2007) 'Le plateau des Boloven et la culture du café, entre division interne et integration régionale', L'Espace géographique, 36(3), pp. 215-228, www.cairn.info/ revue-espace-geographique-2007-3-page-215.htm (accessed on 23 April 2015).

Fox, J. and J.-C. Castella (2013) 'Expansion of Rubber (Hevea brasiliensis) in Mainland Southeast Asia: What are the Prospects for Smallholders?', The Journal of Peasant Studies, 40(1), pp. 155-170, DOI: 10.1080/03066150.2012.750605.

Fox, J. and J.B. Vogler (2009) 'Understanding Changes in Land and Forest Resource Management Systems: Ratanakiri, Cambodia', Southeast Asian Studies, 47(3), pp. 309-329, http://hdl.handle.net/2433/109765 (accessed on 23 April 2015).

Fox, J., D. McMahon, M. Poffenberger and J. Vogler (2008) Land for my Grandchildren: Land Use and Tenure Change in Ratanakiri: 1998-2007 (Honolulu: Community Forestry International (CFI)-East West Center).

Fujita, Y. and K. Phanvilay (2008) 'Land and Forest Allocation in Lao People's Democratic Republic: Comparison of Case Studies from Community-Based Natural Resource Management Research', Society and Natural Resources, 21(2), pp. 120-133, DOI: $10.1080 / 08941920701681490$.

Fullbrook, D. (2011) Smallholder Production Agreements in the Lao PDR: Qualifying Success (Vientiane: Laos Extension Agriculture Project, LEAP), http://www.fao.org/ 
uploads/media/2\%20\%2oSmallholder\%2oProduction\%2oAgreements\%2oin\%20 Lao\%2oPDR-\%2oqualifying\%2osuccess.pdf (accessed on 23 April 2015).

Gebert, R. (2010) Farmer Bargaining Power in the LAo PDR: Possibilities and Pitfalls (Vientiane and Berlin: LEAP-National Agriculture and Forestry Research Institute), http://lad.nafri.org.la/fulltext/2237-o.pdf (accessed on 23 April 2015).

Gironde C. and F. Fortunel (2014) 'Le "boom" de l'hévéa au Cambodge: une conversion hasardeuse pour les petits producteurs autochtones de Ratanakiri?', Fortunel, F. and C. Gironde (eds.) L'Or Blanc, Petits et grands planteurs face au "boom" de l'hévéaculture (Viêt-nam-Cambodge) (Bangkok: Institut de Recherche sur l'Asie du Sud-Est Contemporaine) pp. 143-171, http://www.irasec.com/ouvragen13 (accessed on 23 April 2015).

Goudineau, Y. (2008) 'L'anthropologie du Sud-Laos et la question Kantou', in Goudineau, Y. and M. Lorrillard (eds.) Recherches nouvelles sur le Laos (Vientiane and Paris: E FEO) pp. 639-664.

Gouyon, A. (1995) Paysannerie et hévéaculture dans les plaines orientales de Sumatra, unpublished PhD thesis (Paris: Institut National Agronomique Paris-Grignon).

Guérin, M., A. Hardy, S.T. Boon Hwee and N. Van Chin (2003) Des montagnards aux minorités ethniques: quelle intégration pour les habitants des hautes-terres du Viêt Nam et du Cambodge? (Bangkok: IRASEC).

Hall, D. (2011) 'Land Grabs, Land Control, and Southeast Asian Crop Booms', The Journal of Peasant Studies, 38(4), pp. 837-857, Do I: 10.1080/03066150.2011.607706.

Hall, D., P. Hirsch and T.M. Li (2011) Powers of Exclusion: Land Dilemmas in Southeast Asia (Honolulu: University of Hawai'i Press).

Hansen, K. and N. Top (2006) Natural Forest Benefits and Analysis of Natural Forest Conversion in Cambodia, Working Paper No. 33 (Phnom Penh: CDRI).

Hughes, C. (2003) The Political Economy of Cambodia's Transition 1991-2001 (London and New York: Routledge).

Ironside, J. (2009) 'Poverty Reduction or Poverty Creation? A Study on Achieving the Millennium Development Goals in Two Indigenous Communities in Ratanakiri Province, Cambodia', in Bourdier, F. (ed.) Development and Dominion: Indigenous Peoples of Cambodia, Vietnam and Laos (Bangkok: White Lotus Press) pp. 79-113.

Kenney-Lazar, M. (2012) 'Plantation Rubber, Land Grabbing and Social-Property Transformation in Southern Laos', Journal of Peasant Studies, 39(3-4), pp. 1017-1037, DOI: 10.1080/03066150.2012.674942.

Li, T.M. (2011) 'Centering Labor in the Land Grab Debate', The Journal of Peasant Studies, 38(2), pp. 281-298, D OI: 10.1080/03066150.2011.559009.

Lin, S. (2010) FDI in Agriculture in Northern Lao PDR: A Case Study of Luang Namtha Rural Development in Mountainous Areas of Lao PDR, Component 1: Sustainable Resource Use and Local Economic Development (Vientiane: GTz), http://laocs-kis. 
org/index.php?option $=$ com_sobipro $\&$ task $=$ download.file $\&$ fid $=206.1171 \& \operatorname{sid}=132 \&$ lang=en (accessed on 23 April 2015).

Luangmany, D. and S. Kaneko (2013) 'Expansion of Rubber Tree Plantation in Northern Laos: Economic and Environmental Consequences', Journal of International Development and Cooperation, 19(3), pp. 1-13, http://ir.lib.hiroshima-u.ac.jp/ 00035036 (accessed on 23 April 2015).

Luco, F. (2008) “ "Manger le Royaume"-Pratiques anciennes et actuelles d'accès à la terre au Cambodge', in Forest, A. (ed.) Cambodge contemporain (Bangkok and Paris: IRASEC-Les Indes savants) pp. 419-444.

Manivong, V. and R.A. Cramb (2008) 'Economics of Smallholder Rubber Expansion in Northern Laos', AgroforestrySystem, 74(2), pp.113-125, DOI:10.1007/s10457-008-9136-3.

McAllister, K. (2012) Rubber, Rights and Resistance: the Evolution of Local Struggles against a Chinese Rubber Concession in Northern Laos, paper presented at the International Conference Global Land Grabbing II, October 17-19 (Ithaca: Cornell University), http://www.cornell-landproject.org/download/landgrab2012papers/ mcallister.pdf (accessed on 23 April 2015).

NLMA (National Land Management Authority) (2009-2011) Reports on the 'Findings of State Land Lease and Concession Inventory Project' for the Provinces of Attapeu, Bokeo, Champasak, Khammuan, Luangnamtha, Luangprabang, Saravan, Vientiane, Xayabouly and Xiengkhouang (Vientiane: Land and Natural Resource Information and Research Centre).

Obein, F. (2007) Assessment of the Environmental and Social Impacts Created by the VLRC Industrial Rubber Plantation and Proposed Environmental and Social Plans, Final Report (Vientiane: Agence Française de Développement), http://dev.rightslink lao.org/wp-content/uploads/downloads/2014/o6/04-afd-vlrc_rubber_plantation_ in_bachiang_district.pdf (accessed on 26 May 2015).

Peluso, N.L. and C. Lund (2011) 'New Frontiers of Land Control: Introduction', Journal of Peasant Studies, 38(4), pp. 667-681, DoI: 10.1080/03066150.2011.607692.

Rigg, J. (2006) 'Land, Farming, Livelihoods, and Poverty: Rethinking the Links in the Rural South', World Development, 34(1), pp. 180-202, DOI: 10.1016/j.worlddev .2005 .07 .015 .

Rigg, J., A. Salamanca and M. Parnwell (2012) 'Joining the Dots of Agrarian Change in Asia: A 25 Year View from Thailand', World Development, 40(7), pp. 1469-1481, 10.1016/j.worlddev.2012.03.001.

Ruohomäki, O. (2004) 'Encounters in Borderlands: Social and Economic Transformations in Ratanakiri, Northeastern Cambodia', Moussons, 7, pp. 71-94, http://moussons.revues.org/2482 (accessed on 23 April 2015).

Sallée, B. and J-C. Tulet (2010) 'Développement de la caféiculture paysanne et concessions de terres sur le plateau des Bolovens (Sud Laos): synergie ou antagonisme?', Cahiers d'Outre-Mer, 249, pp. 93-120, DOI: 10.4000/com.5886. 
Schönweger, O., A. Heinimann, M. Epprecht, J. Lu and P. Thalongsengchanh (2012) Concessions and Leases in the Lao PDR: Taking Stock of Land Investments (Bern and Vientiane: Geographica Bernensia), http://www.cde.unibe.ch/vi/CDE/pdf/ Concessions-Leases-LaoPDR_2012.pdf (accessed on 23 April 2015).

Sikor, T. (2012) 'Tree Plantations, Politics of Possession and the Absence of Land Grabs in Vietnam', The Journal of Peasant Studies, 39(3-4), pp. 1077-1101, DOI: 10.1080/03066150.2012.674943.

Simbolon, I. (2002) Access to Land of Highland Indigenous Minorities: the Case of Plural Property Rights in Cambodia, Working Paper No. 42 (Halle: Max Planck Institute for Social Anthropology).

Srikham, W. (2010) The Effects of Commercial Agriculture and Swidden-FieldPrivatization in Southern Laos, paper presented at the RCSD International Conference on Revisiting Agrarian Transformations in Southeast Asia: Empirical, Theoretical and Applied Perspectives, 13-15 May, Chiang Mai, Thailand.

Sturgeon, J. (2012) 'The Cultural Politics of Ethnic Identity in Xishuangbanna, China: Tea and Rubber as "Cash Crops" and "Commodities"', Journal of Current Chinese Affairs, 41(4), pp. 109-131, http://journals.sub.uni-hamburg.de/giga/jcca/article/ view/576/574 (accessed on 23 April 2015).

Tang, S.M. (2014) The Immigrants' Settlement Strategies and Immigration Dynamics within the Framework of Large Scale Lands Acquisitions and their Impacts on Local Populations' Livelihoods in Selected Village of Ratanakiri Province, Cambodia, unpublished Master thesis, Master en Etudes Asiatiques (Geneva: University of Geneva).

Un, K. and S. So (2011) 'Land Rights in Cambodia: How Neo-Patrimonial Politics Restricts Land Policy Reform', Pacific Affairs, 84(2), pp. 287-306, D oI: 10.5509/2011842289.

Vientiane Times Reporters (2015) 'Champasak Moves Towards “Land as Equity” Project Model', Vientiane Times, 14 January, Issue 11, p. 1.

White, J. (1996) 'The Highland People of Cambodia: The Indigenous Highlanders of the Northeast, an Uncertain Future', in Interdisciplinary Research on Ethnic Groups in Cambodia: Final Draft Reports for Discussion at the National Symposium on Ethnic Groups in Cambodia Held in Phnom Penh (Phnom Penh: Center for Advanced Study).

Yem, D., T. Neth and L. Vuthy (2011) Rubber Plantation Development in Cambodia: At What Cost? (Los Banos, Philippines: Economy and Environment Program for Southeast Asia), http://www.eepsea.org/o-k2/view-item/id-397/Itemid-385/ (accessed on 26 May 2015). 